\title{
Model of Incorporation of Emerging Technologies in the Classroom (MIETC)
}

\author{
https://doi.org/10.3991/ijet.v13i06.8226 \\ Edgar Sosa ${ }^{(\varpi)}$ \\ University of Balearic Islands (UIB), Bogotá, Colombia \\ easosan@gmail.com \\ Jesus Salinas, Barbara de Benito Crosetti \\ University of Balearic Islands (UIB), Palma de Mallorca, Spain
}

\begin{abstract}
This work aims to design, implement and validate a model of incorporation of emerging technologies in the classroom using a design-based research methodology through two iterative cycles. In the first iterative cycle, this model was validated by 8 experts and implemented by 13 public school teachers from Bogotá-Colombia. The second cycle was validated and implemented by 25 teachers. A univariate statistical analysis was used to describe the samples in each cycle as well as content analysis to determine the different components of the model. The model is composed of four conditioning factors: motivation, infrastructure, ICT competencies and perceived usefulness; four principles: teacher reflection, pedagogical flexibility, dialogical communication and roles; two recommendations: temporality of the phases and peer-to-peer work and six phases: initial reflection, context analysis, pedagogical foundation, didactic application, implementation and finally evaluation.
\end{abstract}

Keywords-Emerging Technologies, Educational Technology, Models, Learning, Teaching.

\section{$1 \quad$ Introduction}

Incorporating technology in the classroom has been and will be a dynamic and complex process to be carried out by governments, educational institutions, teachers and students due to different social, political, economic and organizational factors, among others [1], which affect positively or negatively the incorporation of technology in teaching and learning processes. For this reason, many educational systems have aimed through policies to improve aspects such as infrastructure and teacher training [2] to generate transformations in educational practice and finally improve the quality of education in some countries. However to achieve this, it is essential to understand that the main agent of change are teachers since they are who decide or not to incorporate technology into their processes [3] [4]. 
Considering the teacher as a transforming agent, it is necessary to know those factors that affect the incorporation of technology in the classroom in order to generate strategies so teachers can acquire the necessary skills to reconfigure traditional paradigms and achieve social change [5], through the use of technology as an effective and efficient means to improve different educational processes. Consequently, this work uses design-based research (DBR) to generate a model of incorporation of emerging technologies (ETs) in the classroom (MIETC) that allows teachers to improve their various teaching processes.

Before describing the method used for the design, implementation and validation of the model, it is necessary to conceptualize Emerging Technologies (ETs) and understand the meaning of a model. ETs refer to resources, artifacts, tools, concepts and innovations associated with digital, that have a disruptive potential to transform or generate changes in the processes where they are used, regardless of whether these are new or old technologies" [6]. This definition, implies two aspects, the first one, is that ETs are contextualized; for example, from the perspective of those schools that have never used technology such as video, mobile applications, augmented reality, this type of technology is considered to be still emergent. On the contrary, it is not emergent for those schools that normally use these resources because students have already been touch with them. The second aspect is that ETs have a very general definition not only because they involve technological tools but also because they refer to innovations that can be made with the use of technology as an inverted classroom or gamification aiming to produce a radical change in the teaching and learning processes [7], [8], [9] and [10].

"A model is a representation of a real object that in the abstract plane man conceives to characterize it and to be able, on that basis, to solve the problem posed, that is, to satisfy a need" [11, p.12]. According to this, a model in the context of the classroom must be composed of different aspects, elements or principles that allow from the characterization and representation of reality to solve a problem of the student or teacher in order to improve the teaching and learning processes. Therefore, "What the models propose in all cases is to configure and structure a practice (application of the model) based on a theory (theoretical part) in an open, adaptable and modifiable way" $[12$, p.35].

\section{Method}

As mentioned above, a Design-based Research (DBR) was used to design, implement and validate MIETC. This methodology focuses on in-depth design and exploration in order to produce artifacts or products [13] that help "understand the relationships among educational theory, designed artifact, and practice. Design is central to efforts to foster learning, create useful knowledge, and advance theories of learning and teaching in complex settings" [13, p.5].

On the other hand, Edelson [14] affirms that from the design three types of theories can be generated; the first, a domain theory which generalizes some part of the problem, that is, describes the learning situations where students, teachers and learning 
environments interact. The second one is about a design framework where the design solution is generalized, which provides a set of design guidelines for particular cases. Finally, the third one refers to design methodologies where guidelines or guidelines are provided to apply the process in order to solve a problem. This work has been mainly framed in this last theory.

Additionally, the DBR is characterized by the following aspects according to Van den Akker, Gravemeijer, McKenney, and Nieveen [15]:

- It is interventionist, because it looks for the design of interventions in the real world.

- Look for the iteration, incorporating a cyclical approach in the design, evaluation and revision.

- It is process-oriented, the important thing is to understand and improve interventions.

- It focuses on utility, since the validity of a design is measured, in part, by the practical nature of its users in real contexts.

- It is oriented to the theory, since the design, at least in part, is based on theoretical propositions, and the in situ design tests contribute to the creation of theory.

There are different models to develop a DBR, such as the Wademan model [16] that consists of 5 phases (identification of the problem from different actors and tentative identification of products, principles of design, tentative products and theories, implementation and preliminary evaluation of products and finally, theories and the solution of the problem and advance of the theory). Plomp's model [17] has three phases, preliminary research, prototype and evaluation. The model of Reeves [18] has 4 phases, which the first one starts from the identification and analysis of the problems by the researcher and collaborative professionals; then, it moves on to the development of solutions based on existing principles and innovations; subsequently, it involves iterative cycles of testing and the refinement of solutions in practice; and, finally, a reflection is carried out to produce the design principles and improve the application that allows to solve the problem. For this work, the Reeves model [18] and the guide proposed by Herrington, Mckeney, Reeves and Oliver [19] have been implemented in order to generate an investigation using the DBR.

\subsection{Phases of the investigation}

This research was developed in 4 phases. The first one is the Analysis of practical problems by researchers and practitioners in collaboration. The problem was defined with the help of researchers and teachers, in addition the research question was determined and the literature review was carried out as well. The second phase is the development of theoretical frameworks informed by existing design principles and technological innovations. The first version of the model of incorporation of Emerging Technologies in the classroom (MIETC) was designed taking into account the results obtained in phase 1 and the experience of researchers in the processes of incorporating technology. 
The third phase refers to the Iterative cycles of testing and refinement of solutions in practice. Two iterative cycles were carried out to implement and validate the model; in the first cycle MIETC was validated by 8 experts and implemented by 13 teachers and the second was assessed by 25 official school teachers from Bogota Colombia. In this last phase, all the suggestions and recommendations of the teachers and experts were analyzed to improve the model. Finally, the fourth phase was a Reflection to produce "design principles" and enhance solution implementation. The research question was answered and the final version of MIETC was developed. For this purpose, the contributions and suggestions of each one of the participants of phase 3 were analyzed through computer programs like the Excel 2013 and ATLAS.ti 8.1 .

\subsection{Instruments}

For phase 1 of the research, two surveys were designed, one for teachers and another for experts in the object of study, both surveys had sociodemographic questions and questions related to the incorporation of technology in the classroom, the purpose of the surveys was to determine the limitations and facilitators so that teachers incorporate technology into their processes. With the results, the MIETC conditioning factors were obtained.

For phase 3, two questionnaires were designed, one for the experts and the other for the teachers. A Likert scale was used for both to validate each one of the components of the model considering degree of agreement, relevance, clarity in the formulation and writing. Additionally, some open questions were placed to give opinions and suggestions about MIETC in the final part of each instrument. The only difference in the instruments is that the teachers were asked about the changes experienced in the teaching and learning processes when implementing the model and the experts were asked if the model designed would allow teachers to improve the different processes in the classroom.

\subsection{Analysis of data}

Because the instruments consisted of both quantitative and qualitative questions, two types of analysis were carried out. The first was a univariate statistical analysis to describe the participants' samples in each of the phases and to determine the degree of agreement, relevance, clarity in the formulation and writing of each of the components of MIETC. The technological tools used for this analysis were Excel 2013 and R x64 3.4.0. The second was a content analysis to openly and axially codify each of the answers, observations and suggestions given by the experts and teachers who participated in this work and allowed the model to be improved. For this analysis, the ATLAS.ti 8.0 and 8.1 were used. 


\section{Results and discussion}

The results and discussion are presented according to each of the phases, emphasizing that phase 4 is where the final model is described.

\subsection{Phase 1}

One of the purposes of this phase was to find the main factors that affect the incorporation of technology in the classroom from the perceptions of teachers and experts, the factors were classified as intrinsic and extrinsic to the teacher. The intrinsic factors are those that are specific to the teacher as: their beliefs regarding the usefulness and ease of use of technology [20],[21],[22],[23],[24],[25],[26],[27],[28]; the intrinsic motivation to decide to incorporate technology [20],[21],[29]; the resistance to change to innovate the educational practice [4],[20],[30],[31],[32] among others; and the extrinsic factors are those external to the teacher and depend on the institutional, national and international policies, some factors found in the literature that affect the incorporation of technology, which are: development of a technology incorporation plan in each institution [20],[31]; provide technical support [20],[21],[31]; open spaces for work among teachers [20],[31]; generate the necessary times to plan the classes [4], [20],[21],[27],[28],[33] and demands of students to use technology [20],[34].

As mentioned above, two surveys were used to determine the factors. The survey was conducted by the 241 teachers, $61 \%$ were women and $39 \%$ men and the age range was between 23 and 64. Reading years of teaching practice, new teachers who had just began their experience were found as well as teachers with 41 years of teaching career. Finally, in terms of geographical distribution, teachers from most of the locations of Bogota-Colombia participated.

With respect to the area of teaching participated: teachers of natural sciences (14.84\%), humanities, Spanish and English language (13.83\%), mathematics $(12.82 \%)$, social science $(12.14 \%)$, artistic education $(9.11 \%)$, ethics and human values $(8.94 \%)$, religious education $(8.09 \%)$, technology and computing $(9.78 \%)$, physical education $(6.75 \%)$ and other areas $(3.71 \%)$ The level of performance of teachers was also varied, $6 \%$ teach in early childhood; $21 \%$ in primary school (first, second, third, fourth and fifth grades); $37 \%$ at the secondary level (sixth, seventh, eighth and ninth grades) and $36 \%$ at the high school level (grades tenth and eleventh).

In the survey applied to the 132 Ibero-American experts who also had the role of teachers, $52 \%$ were men and $48 \%$ were women. The age range was between 26 and 73. Regarding geographical distribution, teachers from 20 countries participated (Colombia $23 \%$, Ecuador $11 \%$, Uruguay $8 \%$, Chile $8 \%$, Mexico 7\%, Peru 6\%, Venezuela $6 \%$, Argentina 5\%, Guatemala 4\%, El Salvador 3\%, Paraguay 3\%, Bolivia 2\%, Brazil $2 \%$, Costa Rica 2\%, Spain 2\%, Honduras 2\%, Panama 2\%, Portugal 2\%, Dominican Republic $2 \%$, Nicaragua $1 \%$ ) and finally, in terms of the maximum level of training reached, $20 \%$ were doctors, $58 \%$ magister, $3 \%$ specialists and the rest had a degree in teaching. It is important to clarify that the participants from Colombia are different from those who participated in the previous survey and the surveys were applied using the forms tool in google. 
As it is observed, a varied sample was obtained, which allows having a greater reliability concerning the obtained data. As for the content analysis of each of the 372 answered surveys, a great variety of extrinsic and intrinsic factors was found for this article, so only the most representative will be mentioned.

The intrinsic factors that positively or negatively affect the incorporation of technology in the classroom are: the teachers' own motivation to decide to incorporate ETs in the classroom; the perceived usefulness to improve teaching and learning processes; ICT competencies, understood as knowledge, skills and necessary attitudes for teachers to incorporate technology [35]; the feelings generated by the use of technology and the resistance to change generated by fear of losing control of the classes and understanding that students are experts in managing technology. The findings related to motivation and utility reaffirm the findings of Sosa et al. [20], Mumtaz [21], Park and Ertmert [29], Yuen and Ma [22] and Zyaan [27], ICT competencies are confirmed according to the study by Carver [28] and Jones [31] and the resistance to change is evident in the study by Villalba et al. [30], Jones [31], Abarzúa and Cerda [4] and Ertmer [32].

The extrinsic factors that positively or negatively affect the incorporation of ETs in the classroom, are: the infrastructure related to the provision of devices, the Internet connectivity, the availability and updating of equipment and programs; initial and permanent teacher training so they can acquire the necessary skills to incorporate technology into their processes; the requirements of the context, mainly regarding the students' needs, the institution, the peers themselves and the district, national and international policies that demand to incorporate technology in the educational processes and the exchange of experiences with other teachers on the ways of integrating ETs in the classroom. Just like the intrinsic factors, the findings regarding infrastructure confirm what was found by authors such as Claro [36], Mumtaz [21], Jones [23], Sosa et al. [20] and Zyand [27], teacher training reaffirms the studies of Jones [31], Zyand [27], Sosa et al. [20] and Ertmer [32], the requirement of context in relation to students was also found in the studies of Kafyulilo et al. [34] and feelings was a finding of Jones [23] and Eickelman [37].

Both extrinsic and intrinsic factors can be facilitators or limiters. This depends on the circumstances of the context and the teacher himself. For example, in an educational institution with excellent infrastructure, this factor becomes a facilitator but that would be all the opposite if the infrastructure is poor. In that case, this factor would represent a limiter. Factors are also relational. For example, when improving teacher training, other factors become facilitators that enhance the development of ICT skills or lower the fear caused by having to incorporate technology in educational processes.

On the other hand, a review of the literature was made in this phase regarding different models. Several ICT incorporation models were found such as: Teaching Model of Integrating Constructivist \& Sociocultural Learning Principles and Information \& Communication Technology [38]; A2I: a Model for Teacher Training in Constructive Alignment for Use of ICT in Engineering Education [39]; MAGDAIRE: a Model to Foster Pre-service Teachers' Ability in Integrating ICT and Teaching in Taiwan [40]; the IRIS Model [41]; a Generic Model for Guiding the Integration of ICT into Teaching and Learning [42]; 4-E Model [43]; A Model for E-education: Extended Teaching Spaces and Extended Learning Spaces [44]; a Two-Dimensional Model for 
Teachers' ICT Integration [45]; a Maturity Model for Assessing the Use of ICT in School Education [46]; Model of ICT Incorporation in the Process of Teaching Innovation for the Implementation of a B-learning [47]; a Five-stage Model of Computer Technology Integration into Teacher Education Curriculum [48]; MITICA Model [49]; TPACK Model [50] and models of instructional designs such as ASSURE, ADDIE, Dick and Carey, among others.

After analyzing the previous models, it was found that these can be classified into two levels at a macro level and even a micro level, at the macro level they explain how technology should be incorporated in institutions and at the micro level a route is provided so that teachers incorporate technology into their educational processes. Additionally, it was found that the models have elements related to didactics, pedagogy, technology, reflection and evaluation.

Finally, in this phase, the research question was drafted. What are the components of the model of incorporation of emergent technologies in the classroom (MIETC) that allow to show changes in the teaching processes through the generation of didactic strategies by the teachers of the official schools of Bogotá-Colombia?

\subsection{Phase 2}

In this phase, the first version of the model was designed taking into account the results found in phase 1 and the experience of the researchers. The model was structured from 3 conditioning factors (motivation, infrastructure and ICT competencies) that are conditions or basic and necessary requirements to be able to implement MIETC, 4 principles (teacher reflection, pedagogical flexibility, dialogical communication and roles) were considered throughout the implementation of the model and 6 cyclical phases (Initial Reflection, analysis of the context, pedagogical rationale, didactic application, implementation and evaluation) to guide the teachers to transform their teaching practice. Additionally, in each of the components of the model, some questions were generated to guide teachers during the implementation of the model. In phase 4 of this section, each of the components of the final model is described, after making adjustments or suggestions found in phase 3 .

\subsection{Phase 3}

The results of this phase are described according to the two iterative cycles that the implementation of MIETC had.

First Iterative cycle: As mentioned earlier in this cycle, MIETC was sent to 8 experts to be validated and it was also implemented and assessed by 13 teachers and based on the results it was adjustmented in order to generate a second version of the model. 8 experts had the title of doctor, 5 in the area of technology educational and 3 in education. 13 teachers had the master's degree related to educational technology, $54 \%$ were women and $46 \%$ men, the average age of teachers was 39.2 within a range between 29 and 55, belonging to various educational institutions, to different teaching areas $(38.4 \%$ mathematics, 30.8\% technology and computer science, $7.7 \%$ social sciences, $7.7 \%$ natural sciences, $7.7 \%$ humanities and English and $7.7 \%$ arts). The 
model was implemented in students from 5 to 16 years old, $8 \%$ corresponding to early childhood, $31 \%$ to primary school, $38 \%$ to secondary school and $23 \%$ to the high school and was implemented in various areas. The results obtained are shown according to the components of the model.

In the conditioning factors (motivation, infrastructure and ICT competencies) $88 \%$ of experts and $100 \%$ of teachers agree with the inclusion of these in MIETC and $12 \%$ of experts do not agree or disagree. In perceived usefulness, $100 \%$ of experts and teachers agree that the conditioning factors are timely and correct. Finally, $75 \%$ of experts and $97 \%$ of teachers say that clarity, formulation and writing is sufficient and excellent, however the rest of teachers and experts say that they can be reformulated.

In the principles (teacher reflection, pedagogical flexibility, dialogical communication and roles) it was found that $100 \%$ of teachers agree with the inclusion and relevance of these in MIETC. However, in the response of experts with regard to the pedagogical flexibility $63 \%$ agree, $25 \%$ neither agree nor disagree and $12 \%$ do not agree in the inclusion of this principle, with the other principles $88 \%$ agree on the inclusion of them. In perceived usefulness, $100 \%$ of experts agree that the principles of teacher reflection and dialogical communication are timely, $88 \%$ agree that the principle of roles is relevant in the model and $75 \%$ agree that the flexibility is also suitable to the model. Regarding clarity, formulation and writing, $96 \%$ of teachers state that they are well formulated and dialogical communication and roles must be rephrased, on the other hand, experts state that the principle of roles and dialogical communication, teacher reflection and pedagogical flexibility in terms of clarity and writing must be reformulated.

In the phases of the model it was found that: in the phase of initial reflection and context analysis, $88 \%$ of the experts and $100 \%$ of the teachers agree with the inclusion of this phase in MIETC, $100 \%$ of the experts and Teachers say they are relevant and only $12 \%$ of experts say they should be reformulated. In the phases of pedagogical foundation and didactic application $100 \%$ of teachers and $75 \%$ of experts agree with the inclusion of these in the model, $100 \%$ of teachers and $88 \%$ say they are relevant and the $25 \%$ of experts suggest reformulating them.

In the implementation phase, $100 \%$ of teachers and $88 \%$ of teachers agree with the inclusion and relevance of this in the model and only $12 \%$ of experts suggest to reformulate it. Finally, in the evaluation phase $92 \%$ of the teachers and $88 \%$ of the experts agree with the inclusion of this phase in the model, $100 \%$ of the experts and $92 \%$ of the teachers state that it is relevant in MIETC and $8 \%$ of the teachers and the $12 \%$ of experts recommend reformulating this phase.

In addition, $92 \%$ of teachers agree that the model of incorporation of Emerging Technologies in the classroom (MITEA) guides them in the process to incorporate ET in the classroom and allowed them to show changes in teaching and learning processes.

Regarding content analysis, it was found that experts recognize that MIETC will allow teachers to improve their teaching and learning processes because it offers a methodological route to incorporate ET in the classroom through a cyclical process (Expert 4); it is easy to implement (Expert 1); its structure is clear and precise in each 
of the components (Expert 8) and it has spaces for constant reflection on the use of technology in the classroom (Expert2; Expert5).

Moreover, teachers evidenced changes in their teaching processes when implementing MIETC because it motivated them to create learning activities according to the needs of the students (Teacher1; Teacher9; Teacher12); it allowed them a greater organization to plan the classes (Teacher2, Teacher3, Teacher4, Teacher8, Teacher13); optimized times, spaces and resources (Teacher2); they transformed their educational practice by using new forms of teaching breaking traditional schemes (Teacher5; Teacher6; Teacher13); it allowed them to train and acquire knowledge in an autonomous way to incorporate technology in the classroom thinking about the good use, the why to incorporate them (Teacher6; Teacher8; Teacher12); and it really reduced levels of frustration (Teacher8).

Among the changes to make the model are: add the conditioning factor of the perceived utility (Teacher 7); determine the timing of some phases because there are some that take place at the beginning of the year (Expert2); involve collaborative work among teachers (Expert2; Expert3; Teacher9); demonstrate the value of the ETs in the implementation phase (Expert7); delimit ICT competencies in the conditioning factor (Expert2); improve the instruments of the didactic application (Teacher6; Teacher13; Expert3); reformulate in terms of clarity and writing the principles of MIETC (Teacher4; Teacher12) and review in a general way the spelling and punctuation of the whole model.

Taking into account the previous suggestions, the second version of the model is generated, a new conditioning factor emerges, the perceived usefulness and 2 recommendations to implement MIETC, the same principles and phases are maintained, some instruments of the phases of the didactic application are redesigned and the implementation and finally the wording and spelling of the whole model was revised.

Second Iterative cycle: The second version of the model was implemented by 25 teachers. $60 \%$ were women and $40 \%$ men, the average age of teachers was 41.1 within a range between 20 and 62 years, belonging to several educational institutions, at different teaching areas (16\% mathematics, $16 \%$ natural and environmental sciences, $12 \%$ humanities, Spanish and English, 12\% natural sciences, 4\% philosophy, $4 \%$ physical education, $4 \%$ dance, $4 \%$ commercial, $4 \%$ plastic arts and $24 \%$ was implemented by teachers who dictate all areas), the model was implemented in students between 4 and17 years old, 16\% corresponding to early childhood, $20 \%$ to primary school, $36 \%$ to high school and $28 \%$ to average and it was implemented in various areas. The results obtained are shown according to the components of the model.

In the conditioning factors, it was found that $100 \%$ of teachers are in agreement with the inclusion and relevance of the motivation and perceived utility in the model, in the infrastructure $92 \%$ agree to its inclusion and $88 \%$ with the relevance of this in the model, in the ICT competencies, $100 \%$ agree on their inclusion and $96 \%$ with the pertinence of this in the model; finally, $100 \%$ affirm that the clarity, formulation and writing is sufficient and excellent. 
In the principles it was found that in teacher reflection, pedagogical flexibility and dialogical communication $100 \%$ of teachers agree with the inclusion of these principles in the model and $96 \%$ agree with the inclusion of the roles as a principle. Regarding relevance, $100 \%$ agree that dialogical communication and roles are appropriate for MIETC and $96 \%$ affirm that Teacher reflection and pedagogical flexibility is relevant; finally, $100 \%$ state that clarity, formulation and writing is sufficient and excellent.

One emerging component after the first iteration of the model were the recommendations, it was found that in the temporality of the phases (recommendation 1), $88 \%$ of the teachers agree with their inclusion and relevance in the work. among peers (recommendation 2) 92\% agree with their inclusion in the model and $88 \%$ state that this recommendation is relevant in MIETC and $100 \%$ state that the clarity, formulation and wording is sufficient and excellent.

It was found in the phases that: in the initial reflection phases, analysis of the context, pedagogical foundation, implementation and evaluation, $100 \%$ of the teachers agree with their inclusion and their relevance in the model, in the didactic application phase. $96 \%$ agree with its inclusion and $100 \%$ with its relevance in the model, in addition all teachers report that clarity, formulation and writing is sufficient and excellent.

Additionally, it was found that $100 \%$ of teachers agree that the model of incorporation of Emerging Technologies in the classroom (MIETC) guides them in the process of incorporation ET in the classroom, $96 \%$ affirm that it allowed them to show changes in the process of teaching and $88 \%$ say that it allowed them to show changes in the learning process of students, finally, comparing the results of iteration 1 and iteration 2, MIETC was improved in each of the aspects evaluated and especially the one related to the clarity, formulation and wording of each of the components.

Regarding content analysis, it was found that teachers evidenced changes in their teaching processes when implementing MIETC because: they made a constant process of reflection on the teacher's task to work on improvements (Teacher2; Teacher4; Teacher11; Teacher13 ); it allowed them to acquire, update and reinforce knowledge about different aspects worked on in the model (Teacher11; Teacher16; Teacher24; Teacher25), it allowed them to carry out an organized process to plan the classes according to the needs of the context (Teacher2, Teacher12, Teacher19, Teacher24); they transformed their educational practice by using new forms and strategies of teaching (Teacher6; Teacher; Teacher; 20) and new forms of evaluation (Teacher10; Teacher22) using ETs; they improved the communication process with students by breaking time-space barriers using technology (Teacher3, Teacher20; Teacher10). Finally, the teachers affirm that the model improves the classroom environment because: it changes the role of the teacher to be a guide and a guide of the process (Teacher5); it allows to teach in a more practical and easier way (Teacher10, Teacher15) and clarity is observed in the teaching and learning process (Teacher4).

Among the changes to make the model are: check in some sections if the guiding questions are repeated and only leave one (Teacher, teacher25); describe and extend the recommendations of the model (Teacher2; Teacher5); deepen pedagogical flexibility not only in the strategies but also in the spaces (Teacher 7). On the other hand, 
teachers make some recommendations to take into account in future implementations: exemplify the model (Teacher12, Teacher23); develop a tool such as an application or software (Teacher23) and make it a little shorter regarding the instruments. These suggestions are not part of the conceptual structure of the model but they will be taken into account in a phase following this investigation.

\subsection{Phase 4}

According to the analysis carried out in a general way to the two iterations and the suggestions of the experts and the teachers, the final version of the model is presented. The model is composed of 4 conditioning factors, 4 principles, 2 recommendations and 6 phases. Figure 1 shows the structure of the model.

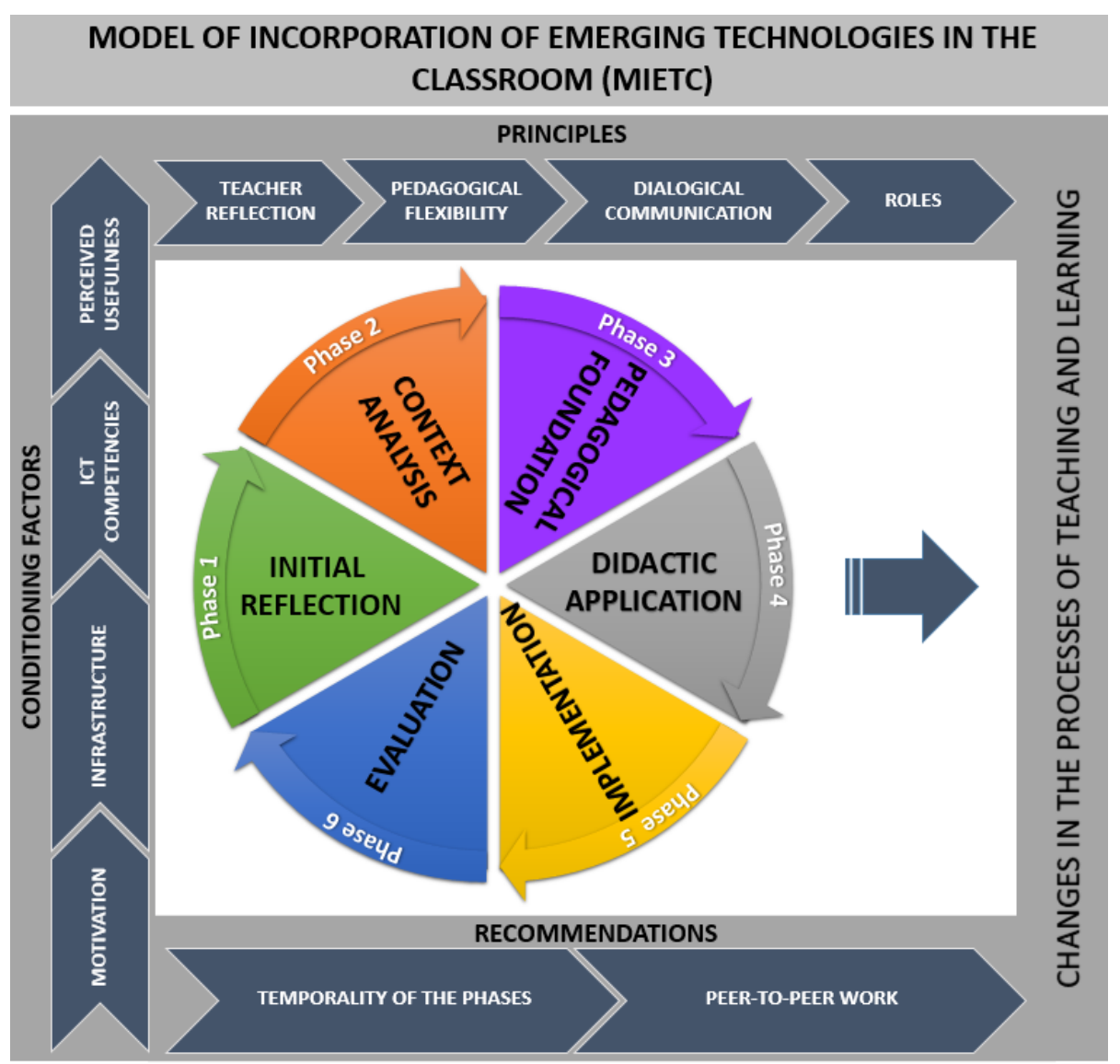

Fig. 1. Model of Incorporation of Emerging Technologies in the Classroom (MIETC)

The conditioning factors of the model are those aspects or requirements teachers have to take into account before the implementation of the model. The first condition- 
ing factor is the motivation that drives teachers to perform actions, activities or strategies in the classroom and maintain the quality of their work [51] to improve teaching and learning processes.

The second conditioning factor is the infrastructure, regarding different services such as internet connectivity, spaces and resources that allow the development of different educational activities [52] related to the incorporation of ETs in the classroom. This infrastructure can generate changes in the teaching practice because they constitute "a basic input for the educational processes and their absence, inadequacy or inadequacy represent additional challenges to the teaching tasks" [53, p.43] or simply continue with the same educational practices and not incorporate ETs due to the lack of resources. According to the research of Gil-Flores et al. [2] availability and access is an obvious requirement to incorporate ICT in the classroom and therefore a requirement to apply MIETC.

The third conditioning factor is ICT competencies regarding "the knowledge, skills and attitudes of teachers when incorporating technology in the classroom" [35, p.11] use of technological, pedagogical, communicative, of management and research [54] that allow the construction, implementation and evaluation of learning environments supported by significant ICTs and contribute to the comprehensive education of the student [55].

The fourth conditioning factor is the perceived utility understood as the extent to which a teacher or individual considers that the use of a particular technology will improve their performance in an activity [56] and [57], that is, if the teacher perceives that ET will improve a teaching or learning process, there is a high probability to incorporate it into the classroom.

Both the motivation conditioning factor, the ICT competencies and the perceived utility are internal factors in teacher, that is, the teacher must overcome these disadvantages in order to implement MIETC from his own initiative. Additionally, they are in a causal relationship, because the motivation and the perceived utility are affected by the confidence in the skills needed to carry out any activity successfully and this can be increased if the necessary skills, knowledge and attitudes are acquired to incorporate technology in the classroom. In order to become competent in ICT teachers need to work on their own training strategies. For Valencia-Molina et al. [55] the strategies can be to learn from others (courses, workshops, diploma courses, seminars, congresses), learn with others (participation in forums, webinar) and learn autonomously (video tutorials, educational videos, reading investigations, massive and open online courses-MOOCS).

The conditioning factor of the infrastructure is an external factor in teachers. For this reason institutions need to have the necessary technological resources to improve the teaching and learning processes. Consequently, it is not enough to provide schools only with technology but also to design training plans for teachers to acquire the necessary skills to incorporate them in a meaningful way. In the first phase of this research it was found that it is necessary to inform the teachers about the resources of the institution to promote using them. Unfortunately, in many cases they have the resources but they don't know how to incorporate them in class, very often because of lack of skills or initiative. 
The principles of the model are the characteristics to be taken into account during the whole process of incorporation of ETs in the classroom. The first principle is the teacher reflection where the teacher must be in constant reflection to pose, face and respond to the problems that arise in the classroom [58] through reflection on action and action, the first refers to a reflection in real time [59] where the teacher makes decisions to refocus their educational practice [60], through questions such as what happens or what will happen, what can be done, how can it be done better, what risks or benefits there is to do an activity [61], and reflection on the action consists of thinking retrospectively about the activity taking into account mainly what worked, what did not work and how it could be improved [59]. The purpose of this principle is not only to seek a quick solution to the problems [62] that can occur during the incorporation of ETs in the classroom but always make a process of reflection to find the best solution. This way MIETC makes this principle explicit in the first and last phase but the teacher must be aware of it in order to implement it all times.

The second principle is the pedagogical flexibility where MIETC must provide a great variety of activities and be able to organize and reorganize them [63] according to the place, the time, the methods, teaching and learning rhythms [64], to the diversity of needs, interests and motivations of students [64] and [65], for this reason teachers must recognize the existence of different contexts and learning styles and from these generate different "learning opportunities" for students to develop the competencies of the 21 st century.

The third principle is the dialogic communication that must be maintained throughout the implementation of the model that allows the different educational actors to learn, develop their personalities, improve their perceptions and abilities to explain and understand the world [66], through an "open and negotiated debate process" in which both students and teachers exchange ideas and opinions [67, p.325] with respect and where the teacher does not manipulate the communication to achieve their goals but to make effective feedback and provide useful information adapted to each student so they can achieve the goals during implementation.

The fourth principle is the roles of the student, the teacher and the Emerging Technology that are used during the implementation. The student is placed in the center of teaching and learning, this implies that they assume an active role [68]. They must be collaborative, responsible, participatory and self-reflective about what, how, where and when they learn and thus they can be aware of their own learning guided by the teacher who have the role of a tutor or advisor in both class activities and extracurricular. Teachers need to encourage students to be committed with their own learning process, discuss with each other, and take advantages of different learning opportunities, continually ask questions, find answers to their questions, discover and structure knowledge, use a variety of resources both analog and digital. Consequently, teacher need to be flexible in the development of the classes, generate authentic activities that arise the curiosity of students, structure and organize the learning process, evaluate and provide feedback to the student [69][70], finally it should be an example of life for the students.

The ETs also play a role within the model and become a transforming agent of teaching and learning processes by being mediating instruments of relationships be- 
tween students and learning contents (for example, searching for information, accessing repositories, use simulators), between teachers and learning contents (e.g. keep track of activities carried out, prepare classes), between teachers and students, or between students themselves (e.g. carry exchange exchanges) communication), who together carry out an activity suggested by teachers (e.g. explaining a topic, providing feedback, keeping track of them) using the instruments that configure learning environments (e.g. use of self-sufficient materials) [71].

The recommendations of the model are those aspects that may vary in the implementation, the first recommendation to implement the model is to take into account the temporality of the phases and this refers to the moments or times in which each of the proposed phases of the model is applied. This depends on the following criteria:

- If this is the first time the model is implemented, start with phase 1 until the end of phase 6, regardless of whether it is applied for the development of a period, a teaching unit or the development of a single class. It is advisable to use it as a gradual process, that is, initially to plan a class, later a didactic unit, then a period, this is for teachers to acquire the experience of using MIETC.

- If the model has been implemented more than once and phase 1 is applied in the same institution and in the same population: Initial reflection and phase 2: Context analysis won't need to be repeated. Only phases 3, 4, 5 and 6 are reconfigured taking into account that in phase 6 corresponding to the evaluation is done at the end of the entire implementation.

The second recommendation is peer-to-peer work, keeping in mind that the purpose of the model is to get teachers to start incorporating ET through a systematic and intentional process, initially autonomously but as they acquire the experience they can work with peers in the next implementations, because this allows them to "recognize and value their own abilities and those of others, and in that exchange, together, imagine, devise, design and make changes in their practices" [72, p.43] related to the incorporation of technology. In addition, peer-to-peer work allows cross-cutting projects that encourage different types of competencies in students.

The phases of the model are those that allow the teacher to carry out a systematic and intentional process when it comes to incorporating ETs into the classroom; additionally, they are cyclical and dynamic, which allows a process of continuous improvement. Next, each one is described.

Phase 1: Initial Reflection is intended to prevent teachers from carrying out activities or strategies in an impulsive and routine way, to elucidate between the purely affective, blind and impulsive of intelligent action and to allow events to advance [73], in order to transform the educational practice and resignify learning spaces from the beginning of any educational activity. In this phase, the teacher must answer the questions. What would be the benefits of incorporating one or more emerging technologies in the classroom for students and teachers? And what could be the main problems that might arise during the implementation of the teaching and learning activities to be developed and how could they be solved?

Phase 2: Context Analysis is carried out in two parts. The first corresponds to the analysis of the context referring to the population; this is done in order to identify the 
main problems of students to learn certain content or to strengthen some skills. This means that the problematic environment is explored to subsequently propose solutions in a general way [74] incorporating ETs and thus improving the teaching and learning processes. If the context is not known and especially to the students it is impossible to generate learning activities that respond to the needs and expectations of them and the current society. The questions that guide this part are: With what course will you work? What are their ages? What are the motivations and interests of the students? What strengths do students have to learn? What limitations do students have in the learning process? In addition, the need to learn or the problem to be solved must be described.

The second part of the context analysis corresponds to identifying the ET's that the institution has, the students and the teachers with the purpose of designing both individual and group activities that make significant use of the technologies. The questions that guide this part are: What emerging technologies does the institution, the students and the teacher have and what are their requirements and availability?

Phase 3: Pedagogical foundation, the teacher determines the purposes of training and the necessary content to develop during the implementation of the model, the purposes and contents must respond to the learning need or problem detected, to the interests, motivations, strengths and weaknesses of the students mentioned in the previous phase. In addition, must be in accordance with the institutional policies (institutional educational project, the pedagogical model, among others) and national (basic competency standards, basic learning rights, among others).

The purposes must answer the question regarding what students should learn through formative and comprehensive statements that guide learning. To build them, the teacher must bear in mind that they are written in terms of what the student is expected to learn and not what he will build or perform to demonstrate his learning [75] (District Education Secretariat, 2012). In addition, in this phase teachers must relate their implementation to the development of 21 st century competencies, according to Binkley et al., [76] who define ten (10) competencies and group them into four (4) categories, the first one is ways of think (creativity and innovation - critical thinking, problem solving and decision making - learning to learn, metacognition); the second one refers to way of working (communication - collaboration and teamwork); in the third one is about tools to work (information literacy - literacy in information and communication technologies (ICT)) and finally live in the world (citizenship, local and global - life and career - personal and social responsibility).

The contents must respond to what students should learn to achieve the purposes of the training, which can be declarative (refers to the learning of facts, data, concepts and principles, these relate to knowledge), procedural (actions ordered to achieve the proposed objective and develop the ability to know) and attitudinal and axiological (values, norms, beliefs, which allow the student to live in peace and harmony within a society, make reference to knowing how to be and knowing how to live together) [77]. Additionally, the metacognitive contents must be worked on in the classroom (they are the necessary learning so students can direct, control, regulate and evaluate his way of learning from the knowledge of themself, of the task and of the strategies 
and thus orient them towards the autonomy that allows them to "learn to learn" and transfer his learnings to their daily life [78].

Phase 4: Didactic application, the teacher must ask himself how to guide the teaching and learning process in the most efficient and effective way, in order to improve and strengthen in students their different knowledge, skills and attitudes. This phase is divided into sequencing, activities, processes, ETs-resources and times.

The sequencing, is the organizational, logical and intentional structure of the different activities, actions and interactions related to each other, necessary to achieve the purposes of training [79], can be for the development of a class or session or for several, it is the teacher's decision to determine the time and following the approaches of Smith and Ragan [80] and Alfonzo [81], it can have three moments, which are initiation, development and closure.

At the beginning, the aim is to prepare the student for the development of the different activities in order to activate attention, establish or say the purpose of training, increase interest and motivation, present the preliminary vision of the activities and investigate the beliefs, knowledge and previous knowledge of students. For this purpose, you can use strategies such as "present new information, surprising, incongruent with the prior knowledge of the student, plan or raise problems, describe the sequence of the task to be performed, relate the content with the previous experiences of the student" [82, p.230], it is generally suggested that this moment means between 10 and $15 \%$ of the implementation.

In the development, new information is presented to the student (explicitly, or what the student investigates) so it can be processed and applied and handled easily. It is necessary focus students' attention, teach activities aimed at promoting learning and generate activities where they can apply and transfer what they have learned in different contexts [80][81], at this time the teacher must spend the a big quantity of time, 60 and $70 \%$.

In the closing it must be observed if the student achieved the purposes of training, for this reason, the teacher should review and summarize what has been worked on, re-motivate and close explaining the importance of what has been learned and propose links with other areas, [80][81]. In addition, a moment should be created for students to perform metacognition of what was worked during the implementation, the time of this phase is between 30 and $15 \%$ of the implementation. The sequencing must answer the question: what is going to do the logical and intentional order of the activities?

The activities are actions designed by teachers for students to carry out and achieve the purposes of training individually or in groups. They must be coherent, meaningful and appropriate to the needs of the students and the context. Currently, there are different types. One of them is the District Education Secretariat [75] that proposes motivational activities, experiential, exemplary learning development and application, but finally, teacher are in charge of deciding the kind of activities to choose for the implementation of MITEA, based on their knowledge and experience. The activities must answer the question How to teach to achieve the purposes of training?

The processes are about describing the way the interaction, evaluation and feedback will be performed during the implementation of MITEA. The interaction is de- 
fined as "a type of communicative activity carried out by two or more participants that influence each other, in an exchange of verbal and non-verbal actions and reactions" [83]. For this reason, the main purpose of using interaction processes is to find common leaning interests between the different actors to achieve the purposes of training using different media, whether they are face-to-face or technological. The evaluation must be conceived as an "integral, dialogical and formative process that favors the achievement of the expected results in terms of learning" [84] and guide the teaching and learning processes. Consequently, the evaluation process should be structured based on the purposes of training and be based on the contents; that's why the evaluation modality is chosen first (who evaluates and when) and then, some evaluative criteria is set (what is evaluated) and finally the evaluation strategy is determined (how it is evaluated) [75]. The feedback refers to how the teacher makes improvement processes to the products, procedures, strategies and self-perceptions [85], it must be carried out at all times and must be linked to the evaluation because, based on the results, the teaching and learning process can be reoriented.

The ETs and resources are those mediations that the teacher uses to support both teaching and learning processes, they can be related to the digital world (tablets, computers, videos, social networks, etc.), which is identified in the phase 2) and the analogical educational resources (guides, board, evaluations, workshops, colors, books, among others). They are subject to the creativity of the teacher, to the possibilities offered by the context and can be elaborated, reused or adapted for their pedagogical relevance, accessibility and usability, recognizing that resources do not determine pedagogical success but rather facilitate the development of learning [75]. In this part, the two important questions are answered regarding, what to teach, and what the function or purpose of the ETs within the implementation is.

Time refers to the duration of the implementation of MIETC, the teacher must ensure that the students are committed to all the activities, which implies understanding the characteristics of all the learners involved. The time can be measured in several scales; for example, for example, the right time for a class or work session would be couple of minutes, but for several classes or sessions the time vary depending of the number of weeks or classes or sessions.

Phase 5: Implementation, materializes what was planned in the previous phase. It is composed of a before, during and after. In the before, a preparation of the spaces and the necessary ETs-Resources for the proposed activities must be carried out. It is important to have a plan B in case any resource or ET fails as well as be able to use instruments to collect information in order to show evidence of the learning process of each student. During the implementation, the student must be constantly informed so that he / she is aware of what is going to happen. The planned activities must be carried out in the didactic application phase, using different instruments to gather information that allow to demonstrate the learning process of each student based on the qualitative and quantitative assessment. It is also necessary to be aware of the changes on the progress that may occur due to extrinsic elements that can vary the didactic application. In the after, the implementation is determined in a general way if the students achieved the purpose of training from the observed, based on the collection of information and of the evaluation processes carried out. In addition, in this part we 
must respond to "How did the incorporation of ETs contribute to achieve the purpose of training?" This question is asked so the evaluation can determine if the incorporation of the ETs affects or not the teaching and learning processes.

Phase 6: Evaluation is carried out once the implementation of MIETC is finished, based on reflexive observations and specifically on the reflective cycle of Gibbs [86] which consists of 6 steps (Description, Feelings, Evaluation, Analysis, Conclusions and Plan of action). With this evaluation, the teacher is expected to evaluate the process carried out and approach to the implementation in a critical way in order to perceive its meanings and become aware of what happened [87] with the intention of reconstructing the educational practice [88] in the incorporation of ETs in the classroom.

According to Gibbs [86] and the Academic Services \& Retention Team, University of Cumbria [89] in the description, the teacher must respond to what happened in the implementation, in an objective, concise and relevant way, in feelings must respond to What were your reactions and feelings?, referring to the various situations experienced, if they were emotions of joy, frustration, stress, despair among others, in the evaluation should answer to what was a good or bad experience?, in the analysis should answer to what sense did you find to the implemented?, and what was really happening? In the conclusions, some answers must be given to questions such as, what can be concluded from the whole experience, if it was positive or negative, what did you learn from the experience?, and what else could I have done to improve the experience?. Finally, the action plan should summarize everything that needs to be known and done to improve the next implementations, for this the teacher must respond to what elements should be taken into account for future experiences?, and what should be done differently next time?

\section{Conclusion}

MIETC provides a route for teachers to begin to incorporate ET in the classroom through a reflective, systematic, intentional and dynamic process in an autonomous way, where the center of learning is the student and technology becomes a mediation that enables changes in the teaching and learning processes. To achieve changes in educational practice, the model proposes four conditioning factors (motivation, infrastructure, ICT competencies and perceived usefulness), four principles (teacher reflection, pedagogical flexibility, dialogic communication and roles), two recommendations (temporality of the phases and peer-to-peer work) and six phases (initial reflection, context analysis, pedagogical foundation, didactic application, implementation and evaluation). Finally, the only conditioning factors that do not allow MIETC to be implemented are the motivation and the perceived usefulness, since the others can be overcome by applying the model itself. It is recommended phases 1 and 2 to be carried out at the beginning of the year or a period and the other phases are developed to plan either one or several classes. Phases 3, 4, 5 and 6 become cyclical phases which aim to improve teaching and learning processes each time MIETC is implemented, taking into account the successes and errors of previous implementations. 


\section{$5 \quad$ Limitations and prospects}

A limitation of this work was the low participation of teachers to implement the model even though in the first and second cycle of iteration they were given a bonus of 35 dollars to participate. Additionally, MIETC should be implemented to more teachers and in different contexts in order to reconfigure the model and finally strategies must be generated to evaluate how effective MIETC is in learning not only from the perceptions of teachers but through standardized tests applied to students.

\section{References}

[1] Butler, D., \& Sellbon, M. (2002). Barriers to adoption technology for Teaching and Learning. Educase Quartely (2), 22-28. Retrieved from https://net.educause.edu/ir/libra ry/pdf/eqm0223.pdf

[2] Gil-Flores, J., Rodríguez-Santero, J., \& Torres-Gordillo, J.-J. (2017). Factors that explain the use of ICT in secondary-education classrooms: The role of teacher characteristics and school infrastructure. Computers in Human Behavior, 68, 441-449. https://doi.org/10.1016/j.chb.2016.11.057

[3] Sing, T., \& Chan, S. (2014). Teacher Readiness on ICT Integration in Teaching-Learning: A Malaysian Case Study. International Journal of Asian Social Science, 4(7), 875-885. Retrieved from http://www.aessweb.com/download.php?id=2817

[4] Abarzúa, A., \& Cerda, C. (2011). Integración curricular de TIC en educación parvularia. Revista de Pedagogía, 32(90), 13-43.Cabellon, E., \& Brown, P. (2017). Remixing Leadership Practices with Emerging Technologies. New directions for student leadership, 2017(153), 9-20. https://doi.org/10.1002/yd.20226

[5] Cabellon, E., \& Brown, P. (2017). Remixing Leadership Practices with Emerging Technologies. New directions for student leadership, 2017(153), 9-20. https://doi.org/10.1002/yd.20226

[6] Sosa, E., Salinas, J., \& De Benito, B. (2017). Emerging Technologies (ETs) in Education: A Systematic Review of the Literature Published between 2006 and 2016. International Journal of Emerging Technologies in Learning (IJET), 12(5), 128-149. https://doi.org/10.3991/ijet.v12i05.6939

[7] Day, G., \& Schoemarker, P. (2000). Avoiding the Pitfalls of Emerging Technologies. California Manage. Review, 42(2), 8-33. https://doi.org/10.2307/41166030

[8] Veletsianos, G. (2010). A Definition of Emerging Technologies for Education. En G. Veletsianos, Emerging Technologies in Distance Education (págs. 3-22). Edmonton: AU Press. Retrieved from http://www.aupress.ca/index.php/books/120177

[9] Rotolo, D., Hicks, D., \& Martin, B. (2015). What is an emerging technology? Research Policy, 44(10), 1827-1843. https://doi.org/10.1016/j.respol.2015.06.006

[10] Kabugo, D., Masagazi, F., \& Muwagga, A. (2015). A Discourse Analysis of TeacherTrainees' Abstract Conceptualizations of Emerging Technologies in Teaching to Revitalise Luganda Language. Journal of Learning for Development (JL4D), 2(3), 16-28. Retrieved from http://j14d.org/index.php/ej14d/article/view/127

[11] Alvarez de Z., C. (1996). La universidad como institución social. Habana: Academia.

[12] Castillo, S., \& Cabrerizo, J. (2005). Formación del profesorado en educación superior: Didáctica y currículum (Vol. I). Madrid: McGraw-Hill. 
[13] Baumgartner, E., Bell, P., Brophy, S., Hoadley, C., Hsi, S., Joseph, D., . . . Tabak, I. (2003). Design-Based Research: An Emerging Paradigm for Educational Inquiry. Educational Design Research, 32(1), 5-8. https://doi.org/10.3102/0013189X032001005

[14] Edelson, D. (2002). Design Research: What We Learn When We Engage in Design. Journal of the Learning Sciences, 11(1), 105-121. https://doi.org/10.1207/S153 27809JLS1101 4

[15] Van den Akker, J., Gravemeijer, K., McKenney, S., \& Nieveen, N. (2006). Educational Design Research. New York:: Routledge.

[16] Wademan, M. (2005). Utilizing Development Research to Guide People Capability Maturity Model Adoption Considerations. Unpublished doctoral dissertation, Syracuse University. New York.

[17] Plomp, T. (2007). Educational design-based research: An introduction. In T. Plomp \& N. Nieveen (Eds.), An Introduction to Educational Design-based research. Proceedings of the seminar conducted at the East China Normal University, Shangai (PR China), November 23-26, 2007(pp. 9-33): SLO Netherlands institute for curriculum development.

[18] Reeves, T. (2006). Design research from a technology perspective. En K. G. J. van den Akker, Educational design research (págs. 52-66). London: Routledge.

[19] Herrington, J., McKenney, S., Reeves, T., \& Oliver, R. (2007). Design-based research and doctoral students: Guidelines for preparing a dissertation proposal. Retrieved from http://doc.utwente.n1/93893/1/Design-based\%20research\%20and\%20doctoral\%20students. pdf

[20] Sosa, E., Salinas, J., \& De Benito, B. (2018). Factors that facilitate or limit the incorporation of emerging technologies in the classroom. International Online Journal of Education and Teaching (IOJET), 5(1), 38-59. http://iojet.org/index.php/IOJET/article/view/343/230

[21] Mumtaz, S. (2000). Factors affecting teachers' use of information and communications technology: a review of the literature. Journal of Information Technology for Teacher Education, 9(3), 319-342. https://doi.org/10.1080/14759390000200096

[22] Yuen, A., \& Ma, W. (2002). Gender Differences in Teacher Computer Acceptance. Journal of Technology and Teacher Education, 10(3), 365-382.

[23] Jones, A. (2004). A review of the research literature on barriers to the uptake of ICT by teachers.Becta ICT Research. Coventry: UK: BECTA British Educational.

[24] Cartelli, A., \& Palma, M. (2008). Encyclopedia of information and communication technology. New York: Information Science Reference.

[25] Ottenbreit-Leftwich, A., Glazewski, K., Newby, T., \& Ertmer, P. (2010). Teacher value beliefs associated with using technology: addressing professional and student needs. Computers \& Education, 55(3), 1321-1335. https://doi.org/10.1016/j.compedu.20 10.06 .002

[26] Buabeng-Andoh, C. (2012). Factors influencing teachers' adoption and integration of information and communication technology into teaching: A review of the literature. International Journal of Education and Development using Information and Communication Technology (IJEDICT), 8(1), 136-155.

[27] Zyand, H. (2016). Integrating Computers in the Classroom: Barriers and Teachers' Attitudes. International Journal of Instruction, 9(1), 65-78. https://doi.org/10.12973/ iji.2016.916a

[28] Carver, L. B. (2016). Teacher Perception of Barriers and Benefits in K-12 Technology Usage. Turkish Online Journal of Educational Technology-TOJET, 15(1), 110-116.

[29] Park, S. H., \& Ertmer, P. A. (2008). Examining barriers in technology-enhanced problembased learning: Using a performance support systems approach. British Journal of Educational Technology, 39, 631-643. https://doi.org/10.1111/j.1467-8535.2008.00858.x 
[30] Villalba, A., González-Rivera, M. D., \& Díaz-Pulido, D. (2017). Obstacles Perceived by Physical Education Teachers to Integrating ICT. TOJET: The Turkish Online Journal of Educational Technology, 16(1), 83-92.

[31] Jones, A. (2004). Enabling teachers to make successful use of ICT. Becta ICT Research. Coventry: UK: BECTA British Educational Communications and Technology Agency.

[32] Ertmer, P. (1999). Addressing First- and Second-Order Barriers to Change: Strategies for Technology Integration. Educational technology research and development, 47(4), 47-61.

[33] Kopcha, T. (2012). Teachers' perceptions of the barriers to technology integration and practices with technology under situated professional development. Computers \& Education, 59, 1109-1121. https://doi.org/10.1016/j.compedu.2012.05.014

[34] Kafyulilo, A., Fisser, P., \& Voogt, J. (2016). Factors affecting teachers' continuation of technology use in teaching. Education and Information Technologies, 21(6), 1535-1554. https://doi.org/10.1007/s10639-015-9398-0

[35] Sosa, E., Salinas, J., \& de Benito, B. (2017). Percepciones de los docentes sobre los factores que afectan la incorporación de tecnología en el aula: Un caso de estudio. XVIII Encuentro internacional Virtual Educa, (pp. 1-15). Bogotá.

[36] Claro, M. (2010). La incorporación de tecnologías digitales en educación. Modelos de identificación de buenas prácticas. Repositorio Digital: Comisión Económica para América Latina y el Caribe. Retrieved from http://repositorio.cepal.org/bitstream/ handle/11362/3772/S2010481.pdf?sequence=1\&isAllowed=y

[37] Eickelmann, B. (2011). Supportive and hindering factors to a sustainable implementation of ICT in schools. Journal for Educational Research Online, 3(1), 75-103.

[38] Nguyen, N., Williams, J., \& Forret, M. (2015), Teaching Model of Integrating Constructivist\& Sociocultural Learning Principles and Information \& Communication Technology. International Journal of Science Educators and Teachers, 1(1),19-40.

[39] Warriem, J., Murthy, S., \& Iyer, S. (2014). A2I: A Model for Teacher Training in Constructive Alignment for use of ICT in Engineering Education. In C. C. Liu, H. Ogata, S. C. Kong \& A. Kashihara (Eds.), Proceedings of the 22nd International Conference on Computers in Education (pp. 896-902). Nara, Japan: Asia-Pacific Society for Computers in Education.

[40] Chang, C., Chien, Y., Chang, Y., \& Lin, Y. (2012). MAGDAIRE: A model to foster preservice teachers' ability in integrating ICT and teaching in Taiwan. Australasian Journal of Educational Technology (AJET), 28(6), 983-999. https://doi.org/10.14742/ajet.806

[41] Siemens, G., \& Tittenberger, P. (2009). Handbook of Emerging Technologies for Learning. Canada, University Manitoba: Manitoba.

[42] Wang, Q. (2008). A generic model for guiding the integration of ICT into teaching and learning. Innovations in Education and Teaching International, 45(4), 411-419.

[43] Collis, B., Peters, O., \& Pals, N. (2001). A model for predicting the educational use of information and communication technologies (4-E Model). Instructional Science, 29(2), 95125. https://doi.org/10.1023/A:1003937401428

[44] Jung, I., \& Latchem, C. (2011). A model for e-education: Extended teaching spaces and extended learning spaces. British Journal of Educational Technology, 42(1), 6-18. https://doi.org/10.1111/j.1467-8535.2009.00987.x

[45] Lin, J., Wang, P.-y., \& Lin, I.-C. (2012). Pedagogy * technology: A two-dimensional model for teachers' ICT integration. British Journal of Educational Technology, 43(1), 97 108. https://doi.org/10.1111/j.1467-8535.2010.01159.x

[46] Solar, M., Sabattin, J., \& Parada, V. (2013). A Maturity Model for Assessing the Use of ICT in School Education. Educational Technology \& Society, 16(1), 206-218. 
[47] Bacigalupo, C., \& Montaño, V. (2008). Modelo de incorporación de tic en el proceso de innovación docente para la implementaciónde un b-learning. Didáctica, Innovación y Multimedia, 11.

[48] Toledo, C. (2005). A five-stage model of computer technology integration into teacher education curriculum. Contemporary Issues in Technology and Teacher Education, 5(2), 177-191.

[49] Fundación Gabriel Piedrahita. (2011). Modelo para integrar las TIC al curriculo escolar. Retrieved from http://www.eduteka.org/modulos/

[50] Mishra, P., \& Koehler, M. (2009). Tpack. Retrieved from http://www.tpack.org/

[51] Pelletier, L., \& Rocchi, M. (2016). Teachers' motivation in the classroom. En W. Liu, J. Wang, R. Ryan, \& (Eds.), Building autonomous learners: Perspectives from Research and Practice using Self-Determination Theory (págs. 107-127). Singapore: Springer Singapore. https://doi.org/10.1007/978-981-287-630-0 6

[52] García, M., Benitez, R., Huerta, V., Medina, M., \& Ruiz, C. (2007). Infraestructura escolar en las primarias y secundarias de México. Mexico: INEE.

[53] Pérez, M., Pedroza, L., Ruiz, G., \& López, A. (2010). La educación preescolar en México. México: Instituto nacional para la evaluación de la educación

[54] Ministerio de Educación Nacional. (2013). Competencias TIC para el desarrollo profesional docente. Bogotá: Imprenta Nacional. Retrieved from http://www.colombia aprende.edu.co/html/micrositios/1752/articles-318264 recurso tic.pdf

[55] Valencia-Molina, T., Serna-Collazos, A., Ochoa-Angrino, S., Montes-González, J., \& Chávez-Vescance, J. (2016). Competencias y estándares TIC desde la dimensión pedagógica: Una perspectiva desde los niveles de apropiación de las TIC en la práctica educativa docente. Cali: Pontificia Universidad Javeriana - Cali. Retrieved from http://www.unesco.org/new/fileadmin/MULTIMEDIA/FIELD/Santiago/pdf/Competencias -estandares-TIC.pdf

[56] Davis, F., Bagozzi, R., \& Warsaw, P. (1989). User acceptance of computer technology: A comparison of two theorical models. Management Sciences, 35(8), 982-1003. https://doi.org/10.1287/mnsc.35.8.982

[57] Davis, F. (1989). Perceived usefulnes, perceived ease of use, and user acceptance of information technology. Mis Quarterly, 13(3), 319-340. Retrieved from http://www.jstor.org/stable/249008

[58] Zeichner, K., \& Liston, D. (2014). Reflective Teaching. New York: Routledge.

[59] Camburn, E., \& Hang, S. (2017). Teachers' professional learning experiences and their engagement in reflective practice: a replication study. School Effectiveness and School Improvement, 28(4), 527-554. https://doi.org/10.1080/09243453.2017.1302968

[60] Pérez, A. (2013). La reflexión sobre la propia práctica en docentes universitarios como mecanismo para reducir el abandono estudiantil. III Clabes- Tercera conferencia latinoamericana sobre el abandono en la educación superior (pp. 1-11). México: UNAM.

[61] Perreneud, P. (2010). Desarrollar la práctica reflexiva en el oficio de enseñar. Barcelona: Editorial Graó.

[62] Korthagen, F., \& Vasalos, A. (2005). Levels in reflection: core reflection as a means to enhance professional growth. Teachers and Teaching theory and practice, 11(1), 47-71. https://doi.org/10.1080/1354060042000337093

[63] Mill, D. (2015). Gestão Estratégica de Sistemas de Educação a Distância no Brasil e em Portugal: a propósito da flexibilidade educacional. Educação \& Sociedade, 36(131), 407426. https://doi.org/10.1590/ES0101-73302015122053 
[64] Salinas, J. (2013). Enseñanza Flexible y Aprendizaje Abierto, Fundamentos clave. In L. Castañeda, J. Adell, \& (Eds.), Entornos Personales de Aprendizaje: Claves para el ecosistema educativo en red (pp. 53-70). Alcoy: Marfil.

[65] Collis, B., \& Moonen, J. (2011). Flexibilidad en la educación superior: revisión de expectativas. Comunicar, 19(37), 15-25.

[66] Niyetbaeva, G., Shalabayeva, L., Zhigitbekova, B., Abdullayeva, G., \& Bekmuratova, G. (2016). Psychological and Pedagogical Conditions for Effective Application of Dialogic Communication among Teenagers. International Journal of Environmental and Science Education, 11(18), 11239-11247.

[67] Kent, M. L., \& Taylor, M. (1998). Building dialogic relationships through the World Wide Web. Public Relations Review, 24(3), 321-334. https://doi.org/10.1016/S03638111(99)80143-X

[68] Onurkan, G., \& Özer, B. (2017). Student-centred learning (SCL): roles changed? Teachers and Teaching: Theory and Practice, 23(4), 422-435. https://doi.org/10.1080/13540 $\underline{602.2016 .1205014}$

[69] Brooks, J., \& Brooks, M. (1993). The case for constructivist classrooms. Alexandria VA: ASCD.

[70] Köğce, D. (2017). A study of pre-service classroom teachers' beliefs about teachers' and students' roles. International Journal of Mathematical Education in Science and Technology, 48(6), 830-848. https://doi.org/10.1080/0020739X.2016.1276228

[71] Coll, C. (2008). Aprender y enseñar con las TIC: expectativas, realidad y potencialidades. Boletín de la Institución Libre de Enseñanza, 72, 17-40. Retrieved from http://www.ub.edu/ntae/dcaamtd/Coll en Carneiro Toscano Diaz LASTIC2.pdf

[72] Cerda, A., \& López, I. (2006). El grupo de aprendizaje entre pares: una posibilidad de favorecer el cambio de las prácticas cotidianas de aula. In M. Arellano, \& A. Cerda, Formación Continua de Docentes: Un camino para compartir (pp. 33-44). Santiago de Chile: Maval.

[73] Dewey, J. (1989). Cómo pensamos. Nueva exposición de la relación entre pensamiento reflexivo y proceso educativo. Barcelona: Paidós.

[74] Nieveen, N., \& Folmer, E. (2013). Formative Evaluation in Educational Design Research. En J. Van den Akker, B. Bannan, A. Kelly, N. Nievenn, \& T. Plomp, Educational Design Research (págs. 152-169). Enschede, Netherlands: SLO, Enschede. Retrieved from http://international.slo.nl/publications/edr/

[75] Secretaría de Educación Distrital. (2012). Ambientes de Aprendizaje para el Desarrollo Humano (Vol. 3). Bogotá: Secretaría de Educación Distrital. Retrieved from Herramienta de consulta y orientación para el diseño e implementación de ambientes de aprendizaje.

[76] Binkley, M., Erstad, O., Hermna, J., Raizen, S., Ripley, M., Miller-Ricci, M., \& Rumble, M. (2012). Defining Twenty-First Century Skills. In P. Griffin, E. Care, \& B. McGaw, Assessment and Teaching of 21st Century Skills (pp. 17-66). Dordrecht: Springer.

[77] Coll, C., Pozo, J. I., Sarabia, B., \& Valls, E. (1992). Los contenidos en la Reforma: Enseñanza y Aprendizaje de Conceptos, Procedimientos y Actitudes. Madrid: Santillana.

[78] Osses, S., \& Jaramillo, S. (2008). Metacognicion: un camino para aprender a aprender. Estudios pedagógicos (Valdivia), 34(1), 187-197. https://doi.org/10.4067/S071807052008000100011

[79] Pérez, M. (2015). Un Marco para Pensar Configuraciones Didácticas en el Campo del Lenguaje, en la Educación Básica. En F. (. Vásquez, Didáctica de la lengua materna. Estado de la discusión en Colombia (págs. 47-65). Cali-Colombia: Icfes-Univalle.

[80] Smith, P., \& Ragan, T. (1999). Instructional design. New York: Wiley. 
[81] Alfonzo, A. (2003). Estrategias instruccionales. Retrieved from https://ecaths1.s3.amazonaws.com/didacticadeladanzai/1464538619.estrategias.pdf

[82] Feo, R. (2010). Orientaciones básicas para el diseño de Estrategias Didácticas. Tendencias Pedagógicas (16), 220-236.

[83] Jauregui, k. (2012). La interacción, elemento clave en el proceso de aprendizaje de ELE. Plurilinguismo y enseñanza de ELE en contextos multiculturales. XXIII Congreso Internacional ASELE (pp. 5-16). Girona: Asociación para la Enseñanza del Español como Lengua Extranjera.

[84] Secretaría de Educación Distrital. (2015). Reorganización curricular por ciclos: Ruta para la consolidación de planes de estudio, en el marco del currículo para la excelencia académica y la formación integral. Bogotá: Secretaría de Educación Distrital.

[85] Paoloni, V., Rinaudo , M., \& González, A. (2011). Procesos de retroalimentación en la autorregulación de recursos de aprendizaje. Explorando su potencial en el contexto de la universidad. RED - Revista de Educación a Distancia. Sección de docencia universitaria en la Sociedad del Conocimiento, 3, 1-18. Retrieved from http://www.um.es/ead/red dusc/3/paoloni et al.pdf

[86] Gibbs, G. (1988). Learning by doing: a guide to teaching and learning methods. Oxford: Further Education Unit, Oxford Polytechnic.

[87] Nocceti, A. (2015). El ciclo de aprendizaje reflexivo como dispositivo para estimular la reflexión y el cambio docente en la práctica profesional. VIII Jornadas Nacionales y $1^{o}$ Congreso internacional sobre la Formación del Profesorado, (págs. 1-19). Mar del plata. Retrieved from http://www.mdp.edu.ar/humanidades/pedagogia/jornadas/jprof2015/ponen cias/nocetti.pdf

[88] Peñas, M., \& Flores, P. (2005). Procesos de reflexión en estudiantes para profesor de matemáticas. Enseñanza de las Ciencias, 23(1), 5-16.

[89] Academic Services \& Retention Team, University of Cumbria. (2015). Gibbs' reflective cycle. Retrieved from http://my.cumbria.ac.uk/Public/LISS/Documents/skillsatcumbria/ $\underline{\text { ReflectiveCycleGibbs.pdf }}$

\section{$7 \quad$ Authors}

Edgar Andres Sosa Neira, PhD student in Educational Technology from University of the Balearic Islands (UIB - Spain), master in Educational Informatics from University of La Sabana (Colombia), currently serving as a lecturer at the District Education of Secretariat (Bogotá), researcher and teacher at the Autonomous University of Manizales. Belonging to the District Network of Research Teachers and interested in Educational Technology research.

Jesus Salinas received his $\mathrm{PhD}$ from the University of Balearic Islands (UIB), Spain. Director of the Institute of Research and Innovation in Education, professor of Educational Technology and senior researcher in the Educational Technology Group. Director of Edutec-e Electronic Journal of Educational Technology, and consultant for several universities in different countries on issues of technology integration in higher education. His research interest includes E-Learning, Self-Regulated ELearning, E-Learning Design, online PhD supervision, and Personal Learning Environments.

Barbara de Benito Crosetti is lecturer of Educational Technology at the University of Balearic Islands (UIB). Researcher at Education Technology Group from UIB, 
since its creation in 1992, working in $\mathrm{R}+\mathrm{D}$ projects. Founder member and advisor to the spin-off Zairja, S.L. (Training and Knowledge Management Solutions). Member of EDUTEC (Association for the development of education technology). Member of Congress Scientific Committees associated with Education Technology, e-learning, distance learning (eg, EDUTEC, IADIS). Has written various articles and made contributions at conferences on Education Technology.

Article submitted 11 January 2018. Final acceptance 20 March 2018. Final version published as submitted by the authors. 